\title{
Dewar Dosing Unit
}

National Cancer Institute

\section{Source}

National Cancer Institute. Dewar Dosing Unit. NCI Thesaurus. Code C62415.

A dosing unit equal to the amount of active ing redient(s) contained in a dewar. 